\title{
FORMATION OF A CULTURE OF TOLERANCE AMONG STUDENTS
}

\author{
Nikolay A. Efremov ${ }^{1 *}$, Dagmar Kalátová ${ }^{2}$, Natalia V. Morozova ${ }^{3}$, \\ Evgeniya O. Andreyko ${ }^{4}$, Tatiana V. Muzhzhavleva ${ }^{5}$, Marina P. Efremova ${ }^{6}$, \\ Ansell Lammert ${ }^{7}$, Inessa A. Vasileva ${ }^{8}$, Natalia V. Bondarenko ${ }^{9}$ \\ ${ }^{1}$ Assoc. Prof. Dr., I.N. Ulianov Chuvash State University, CHUVASH REPUBLIC, RUSSIA, \\ dr_lammert@vk.com \\ ${ }^{2}$ Prof. Dr., St. Elizabeth University of Health and Social Sciences, SLOVAC REPUBLIC, \\ KalatovaD@seznam.cz \\ ${ }^{3}$ Assoc. Prof. Dr., I.N. Ulianov Chuvash State University, CHUVASH REPUBLIC, RUSSIA, \\ morozovanw@mail.ru \\ ${ }^{4}$ Assoc. Prof. Dr., Gnesin Russian Academy of Music, RUSSIAN FEDERATION, \\ muggenol@mail.ru \\ ${ }^{5}$ Prof. Dr., I.N. Ulianov Chuvash State University, CHUVASH REPUBLIC, RUSSIA, \\ csaprdom@mail.ru \\ ${ }^{6}$ Assoc. Prof. Dr., I.N. Ulianov Chuvash State University, CHUVASH REPUBLIC, RUSSIA, \\ mp.cherdakova@yandex.ru \\ ${ }^{7}$ Dr., St. Elizabeth University of Health and Social Sciences, SLOVAC REPUBLIC \\ anselllammert@seznam.cz \\ ${ }^{8}$ Asst. Prof. Dr., I.N. Ulianov Chuvash State University, CHUVASH REPUBLIC, RUSSIA, \\ inka107@mail.ru \\ ${ }^{9}$ Assoc. Prof. Dr., I.N. Ulianov Chuvash State University, CHUVASH REPUBLIC, RUSSIA, \\ bondarenkonatalia@mail.ru \\ ${ }^{*}$ Corresponding author
}

\begin{abstract}
The formation of a culture of tolerance is one of the tasks of upbringing. Throughout their life, a person learns to be tolerant towards other people and to respect and accept others as they are. It is very important that, in adolescence, a person understands that not only success in life and career, but sometimes life itself, depends on their level of tolerant behavior and consciousness of others.
\end{abstract}

This article is devoted to the topic of tolerance in modern pedagogy, which is the most important component of humane pedagogy. In the light of new socio-economic and political upheavals, the topic of the formation of a culture of tolerance in the process of pedagogical activity is relevant.

The purpose of this study is to establish the levels of formation of a culture of tolerance in the process of pedagogical activity.

During the analysis, we conclude that the formation of tolerance consists in the passage of three levels of educational results.

At the first level, the teacher must give the child "moral knowledge" about what tolerance is, what is the value of modern society, and that there are different cultures, nationalities, religions in the world that can and must 
peacefully coexist and interact. At the same time, the child may well not share and not accept this "moral knowledge". Even if the child is not able to realize this, the main thing is that they be familiar with it.

At the second level, the teacher must create conditions for the development of the child's "moral skills" - the ability to work in a team, the ability to listen and hear another, to negotiate with them, to accept the differences between the other person and themself and take those differences into account when communicating and interacting, and the ability to resolve conflict situations with dignity and tact. Again, the main thing is to show how to act correctly and to give the child the opportunity to show all these skills in a playful situation. But in a real-life situation, the child may not be interested in using them.

The third level, the most desirable and difficult to achieve - "moral mastery" - depends not only on the teacher but also on the child themself, on their environment. This is the child's internal acceptance of moral values as their own and the only possible behavior in situations of choice is in accordance with them. This is where educational and educational efforts are directed.

Keywords: Humane Pedagogy, Modern Pedagogy, Tolerance.

\section{INTRODUCTION}

Public thought always has sought to determine the ways of establishing loyal, nonaggressive, benevolent relationships between people belonging to different social strata, ethnic groups and religions, and states. One of the principles of such desirable benevolent relations - the principle of tolerance - is enshrined in state laws, international treaties, and declarations of the world community. Tolerance is an elusive and at the same time invariable ideal. It belongs not only to outstanding and conscientious thinkers, but also an acceptable and desirable moral norm of ordinary citizens of a law-governed state.

All over the world, people are concerned with the problem of tolerance. In 1995, UNESCO adopted the Declaration of Principles of Tolerance, 2000 was proclaimed by the UN General Assembly as the International Year for the Culture of Peace, 2001 - The Year of Dialogue of Cultures and Civilizations under the auspices of the UN, 2001-2010 - The International Decade for a Culture of Non-Violence and Peace for the Children of the World.

For the Russian Federation, as a multinational state with many religions, the issue of tolerance is very important, and its importance increases during periods of socioeconomic and political instability.

In translating the moral ideal of tolerance into life, the emphasis, of course, should be placed on fostering tolerance in the youngest generation. This is one of the main tasks of the system of state basic general education, and therefore one of the important areas of work of teachers. The Federal Law No. 273-FZ „On Education in the Russian Federation" (as amended on September 1, 2021) notes the need to promote mutual understanding and cooperation between people and nations regardless of racial, national, ethnic, religious, and social affiliation; all must consider the diversity of worldview approaches.

Naturally, tolerance and non-conflict, the ability to work in a group and live in a team do not appear on their own. Rather, these qualities must be formed purposefully. Turning to the importance of tolerance for everyone, and not just for society, it should be noted that how the process of cognition and resolution of contradictions and conflicts is organized at all stages of a child's growing up, will depend on their life in an adult society and their successful socialization.

\section{WHAT IS TOLERANCE}

Before talking about the education of tolerance, one should dwell on what exactly is put into this concept.

The concept of "Tolerance" was introduced into scientific circulation in the 18th century. In Russia, the concept of tolerance began to be used in the liberal press from the mid-19th century, but from the mid-1930s it disappeared from political vocabulary until it reappeared in the early 1990s (Semashko, 2007).

Tolerance in sociology and psychology is the ability to calmly, without hostility, perceive someone else's way of life, behavior, customs, feelings, opinions, ideas, beliefs, to recognize the right to exist of other cultures, and to coexist sustainably in a multicultural, multi-ethnic society (Yamburg, 2014).

According to the psychological and pedagogical definition, tolerance is a moral and ethical quality of a 
person, characterized by a person's ability to accept another in all their diversity, to recognize individuality, to respect one's own and other people's opinions and views (Bezyuleva and Shelamova, 2003).

In accordance with the Declaration of Principles of Tolerance, approved by Resolution 5.61 of the UNESCO General Conference of November 16,1995, tolerance is defined as follows: "the value and social norm of civil society, manifested in the right of all individuals in civil society to be different, to ensure sustainable harmony between different faiths, political, ethnic and other social groups, respect for the diversity of various world cultures, civilizations and peoples, readiness to understand and cooperate with people who differ in appearance, language, convictions, customs and beliefs" (Declaration of Principles of Tolerance, 1995).

The characteristic of the definition of tolerance in the Preamble of the UN Charter reads as follows: "to show tolerance and live together, in peace with each other, like good neighbors". Here, the lexeme receives not only an effective, socially active coloring, but is also viewed as a condition for successful socialization (integration into the system of social relations) (Declaration of Principles of Tolerance, 1995).

Mcheldov M.P. emphasizes that tolerance is a quality of the culture (moral, legal, political) of every society, every social stratum, every citizen, regardless of gender, age, ethnicity, or race.

There are different forms of tolerance: 1.) personal, 2.) public (reflected in morality, morals, social psychology, consciousness), and 3.) state (reflected in legislation, political practice).

Various definitions of tolerance and approaches to it fit well into this scheme: personal tolerance acts as a moral and ethical quality of the individual, and public and state - as a value and cultural norm.

Also, Mcheldov M.P. highlights the basic requirements of a tolerant culture: free practice by each citizen, social group, society of freely chosen moral, socio-political, ideological preferences presupposes their loyal, tolerant, non-hostile, respectful attitude to the similar choice of others (Mchedlov, Ojzerman, Mchedlova, Loginov, and Kafanova, 2004).

Thus, an important component of tolerance is the understanding of attitudes, morals, habits, feelings, methods of action that are different from ours. Hence, the first task of fostering tolerance in school begins with acquaintance with the foundations of other cultures and the emergence of interest in them. Recognizing the right to difference is the foundation of tolerance.

Adherence to tolerant moral attitudes in everyday life can help create comfortable living conditions for a person, neutralize aggressive, conflicting relationships. At the same time, such behavior is an indicator of the intellectual level of a person who is ready to enrich and improve his mental outlook, disposition, and demeanor through contacts with other views and practical actions.

On the other hand, tolerance does not mean concession or connivance to any ideological system and political position; and this is by no means indifference, indifference to any views and actions, just as it is not humility in the face of social or everyday evil. An artificial desire to achieve complete "consent" will inevitably turn into even greater evil. Compliance with the requirements of tolerance excludes conciliation towards violations of legal and moral norms (Mchedlov, Ojzerman, Mchedlova, Loginov, and Kafanova, 2004).

Indifference is unacceptable when immoral and illegal socio-economic and political actions are committed. Also, one must not put up with views, the error of which is reliably and experimentally proven. A different matter is the sphere of personal culture, and even more so of ideological convictions, ethnic values, social and cultural, including religious, norms. It is impossible to say with certainty which culture, religion, ethical system, socio-political doctrine is truer, better, and more optimal than others.

\section{MODERN TEACHERS AND TOLERANCE}

In modern society, tolerance is not just an abstract humanistic value; it is enshrined in regulatory documents, and for teachers, it is one of the mandatory areas of work.

The Federal Law of the Russian Federation "On Education in the Russian Federation" of December 29, 2012, N 273-FZ (as amended on September 1, 2021) contains the following provisions regarding tolerance (On Education in the Russian Federation, 2021):

- Art. 5.2. The right to education in the Russian Federation is guaranteed regardless of gender, race, nationality, language, origin, property, social and official status, place of residence, attitude to religion, beliefs, membership of public associations, and other circumstances (On Education in the Russian Federation, 2021).

- Art. 66.2. Basic general education is aimed at the formation and formation of the student's personality (the 
formation of moral convictions, aesthetic taste, a healthy lifestyle, a high culture of interpersonal and interethnic communication, mastering the basics of science, the state language of the Russian Federation, mental and physical labor skills, the development of inclinations, interests, and abilities of social selfdetermination) (On Education in the Russian Federation, 2021).

According to the above articles, a modern teacher, firstly, must be able to work with a collective of children of different nationalities and religions, considering their peculiarities and not offending their national and other feelings, and secondly, educate students in a spirit of peacefulness and tolerance (On Education in the Russian Federation, 2021).

Povarenkov Yu.P. identifies pedagogical tolerance as a special type, including the social and psychological tolerance of the teacher: "The presence of social tolerance allows the teacher to effectively interact with all participants in the educational process, and the formation of psychological tolerance ensures the teacher's high resistance to numerous professional stresses and contributes to the effective construction of his professional career" (Novikov, Nizhegorodczeva, Zlotnikova, Erokhina, and Ledovskaya, 2011).

According to the Order of the Ministry of Labor and Social Protection of the Russian Federation of 18.10.2013 N 544n (as amended on August 05, 2016) "On the approval of the professional standard" Teacher (pedagogical activity in the field of preschool, primary general, basic general, secondary general education) (educator, teacher)", the formation of tolerance is enshrined as an obligatory function of the teacher and in the new normative document that regulates pedagogical activity and creates requirements for pedagogical workers (Yamburg, 2014).

In the above professional standard, among the labor actions of a teacher, it is indicated "the formation of tolerance and behavior skills in a changing multicultural environment", as well as "the formation of tolerance and positive samples of multicultural communication" (Yamburg, 2014).

Yamburg E.A., the head of the group of developers of the concept of the professional standard of a teacher, rightly notes: "The world is changing, children are changing, which, in turn, puts forward new requirements for the qualifications of a teacher. But one cannot demand from a teacher what no one has ever taught him. Consequently, the introduction of a new professional standard for a teacher should inevitably lead to a change in the standards of his training and retraining in higher education and in centers for advanced training" (Yamburg, 2014).

The most productive development of the problem of forming a culture of interethnic communication in the Russian Federation began in the 1990s and was directly related to the events in Dagestan, Chechnya, where there was an increased threat of terrorism and extremism.

Hasanov Z.T. in the monograph "Education of the culture of interethnic communication: methodology, theory, practice", based his work on the revision of the methodology and theory of education of Soviet patriotism, friendship of peoples, and formulated and developed a modern theory of education of patriotism, friendship between peoples, and tolerance, and revealed its essence and content. As a result, the course "Pedagogy of interethnic communication" was developed, aimed at solving the following problems (Grigoriev, Stepanov, 2010):

- Fostering deep respect for the multinational people of Russia and love for the Fatherland in order to strengthen the unity of the federal state (Grigoriev, Stepanov, 2010);

- Cultivating a respectful attitude towards people of various nationalities of the country, towards their languages, and social values; fostering deep respect for the peoples inhabiting a common homeland (Grigoriev, Stepanov, 2010);

- Orientation towards universal human moral values, towards the best achievements of human civilization, towards the awareness of belonging to the world community (Grigoriev, Stepanov, 2010);

- Education in the spirit of peace and respect for all peoples of the Earth and their ethno-national characteristics; appeal to the national dignity and feelings of people (Grigoriev, Stepanov, 2010);

- Stimulating an intolerant attitude towards manifestations of chauvinism, nationalism, and racism; education in the spirit of tolerance for religious feelings of people, ensuring the peaceful resolution of emerging conflicts of cultures at the junction of religions (Grigoriev, Stepanov, 2010).

Thus, this course is aimed at the implementation of state policy that promotes the friendship of peoples, the idea of instilling respect for people in the younger generation, tolerance, and the desire for peace. He prepares his students to continue this line in relation to their own students in future teaching activities. 


\section{FORMATIONS OF TOLERANCE AMONG STUDENTS}

Educational psychologists approach the concept of tolerance as a moral and ethical quality of a person.

With the desire to form any personality traits through educational influence, it is necessary to understand that this process is not simple, but instead multifaceted and multi-stage.

Likhachev D.S. argues that the result of moral education is the formation of a morally integral personality, consisting of the unity of one's consciousness, moral feelings, conscience, moral will, skills, habits, socially valuable behavior (Likhachev, Shmidt, Zholud, and Yakovlev, 2006).

Modern pedagogy, in addition, distinguishes between the "result" and the "effect" of the impact of education on the child. The result is the direct result of the student's participation in the activity or event. An effect is a consequence of the result, the influence of some spiritual and moral acquisition on the process of development of the child's personality (Grigoriev, Stepanov, 2010).

The development of a child's personality depends on their own self-building efforts, on the educational "contributions" of their family, friends, closest circle, and other factors. The development of a child's personality is an effect that is made possible by several subjects of education and socialization (including the child himself) achieving their results. Therefore, it would be completely unreasonable to expect, because of an educational event (or even a system of such events, united by a single goal), the direct formation of tolerance and other personality traits. We, as teachers, can only contribute to the complex and multifaceted mechanism that is the formation of a child's personality and hope for a planned (but always delayed in time) effect.

The likelihood of positive effects of upbringing and socialization of children is increased when they achieve three levels of results (Grigoriev, Stepanov, 2010):

- the first level of results is the acquisition of social knowledge by the student, a primary understanding of social reality and everyday life. If we, as teachers, want to form tolerance among schoolchildren, then first we must organize conversations and discussions about what tolerance is, and what its role and significance in modern society is. We must acquaint children with the diversity of cultures and religions of the world to show their peculiar beauty and awaken interest in the traditions of other peoples. We also must acquaint them with the rules of good-neighborly relations and methods of peaceful settlement of interpersonal contradictions, no matter on what basis they arise. Convincing the value of friendship, team cohesion (Grigoriev, Stepanov, 2010);

- the second level of results is when the schoolchild gains experience and a positive attitude towards the basic values of society. To achieve this level of results, the interaction of schoolchildren with each other at the level of the classroom, in school, must be in a secure, friendly, pro-social environment. It is in such a close social environment that the child receives their first practical confirmation of acquired social knowledge and begins to value them (Grigoriev, Stepanov, 2010).

At this stage, the role of the teacher in the formation of tolerance and their ability to work in a team is reduced to the creation of special situations of communication and interaction between schoolchildren, to the skillful management of their activities, and to a civilized settlement of emerging conflicts. In the classroom, it boils down to the organization of group work for students. In extracurricular activities and in camps, it is manifested in games, collective creative affairs, and trainings. It should be said that all the listed forms of organizing the activities for children have the potential to develop tolerance and the ability to work in a team. But they "work" only when they are conducted with this clear purpose, and not just to fill the "temporary void"; the teacher must skillfully accompany the process of communication and interaction of children, encouraging their "correct" behavior and correcting the "wrong" ones.

D.S. Likhachev drew attention to the fact that games disappear from the life of children, and it is in the process of playing that team spirit and other important social qualities develop: "Games disappear altogether. They are replaced by dancing, or what is called dancing. Meanwhile, games are very important in educational terms. The game - be it rounders, volleyball, burners, or some other kind - fosters sociality, it fosters the ability to stick together, play together, feel a partner, feel an opponent. This is a very important educational thing - play. Games must be revived in our lives" (Mchedlov, Ojzerman, Mchedlova, Loginov, and Kafanova, 2004).

He also lamented the disappearance of "live", real communication between people (and it is in this process that a true tolerant consciousness is formed): "And how few contacts between people we have now. They are very important, direct contacts, intuitive contacts of some kind, which were organized in games, in choral 
singing, in music. Therefore, it is necessary to pay attention to pedagogical organizations to this side of our life, to the fact that games are leaving our life" (Mchedlov, Ojzerman, Mchedlova, Loginov, and Kafanova, 2004);

- the third level of results is the schoolchild's gaining experience of independent social action. Only in independent social action, outside the friendly environment of the school and among strangers, does a young person really show and strengthen their personal qualities to become a social activist and a citizen. An important role "in real life" is played by the teacher's lack of assessment, but the child responds both to their internal self-assessment of their actions and the public one, which reflecting the values of the social group within which the child lives. Often the humanistic values "preached" by the teacher, including tolerance, conflict with the attitudes of the family, or the social environment of the child. Of course, we (teachers) really want our students to act with dignity outside the school, but this is not always the case. In this case, does the blame completely fall on the shoulders of the teacher - "poorly brought up"? Let us remember that the educational result is not yet equal to the effect. And we must rationally treat the fruits of our labor, which is based on idealistic goals, but dictated by the impact on the child by the social environment. Alas, teachers are not omnipotent, otherwise humanity would have long lived in peace and harmony, without crimes and wars. On the other hand, this is not a reason to show indifference towards those pupils whose fate may seem predetermined.

About tolerance, some qualities of temperament depend on the national character, and the standards of behavior that a child learns are mainly influenced by strong traditions and religious education within the family.

Thus, Albert Bandura, a representative of the socio-cognitive trend in personality theory, noted the enormous importance of learning through modeling: a child "absorbs" the behavior of a model (parents) that is significant for them, and then represents and reproduces it (Khell, Zigler, 2008).

Vygotsky L.S. also speaks of a child's "social developmental situation", a space in which they learn this or that attitude to reality and other people not only in the process of specially organized learning, but also by imitation, learning the ways of behavior and response inherent in significant adults (Novikov, Nizhegorodczeva, Zlotnikova, Erokhina, and Ledovskaya, 2011).

If the behavior shown and approved in the child's environment does not coincide with the humanistic values of tolerance that the teacher is trying to instill, the assessment of the teacher's upbringing activity should be carried out not according to the educational effect, but according to the number and quality of their efforts and actions. At the same time, the teacher themself is included in the "social situation of development" of their students. Their own professional tolerance is a necessary condition for the formation of tolerance among students. Otherwise, if the teacher is internally not tolerant, they will not be congruent on this issue, and their attempts to educate children in a spirit of tolerance will be in vain.

\section{CONCLUSIONS}

In accordance with the Declaration of the Principles of Tolerance, tolerance is a value and social norm of civil society, manifested in the right of all individuals of civil society to be different, which ensures sustainable harmony between different confessions and political, ethnic, and other social groups, as well as respect for the diversity of various world cultures, civilizations, and peoples. It involves willingness to understand and cooperate with people who differ in appearance, language, convictions, customs, and beliefs.

Tolerance is not a tolerant attitude towards injustice, not a rejection of one's own ideals or a concession to other people's convictions, not condescension and not connivance, but an active attitude, a recognition and a respect for human rights and freedoms. As a result of tolerant behavior, opportunities for reaching agreements between different people expand due to the enrichment of their own experience and the variability of communication with other people who differ from them.

At the present time, when each state at the national level has developed a program for the development of a tolerant consciousness, when there is a solid legal basis for neutralizing manifestations of extremism, the difficult and long-term task of ensuring the real implementation of the course taken by the state comes to the fore.

The school, as the most important social institution, is called upon to help in this. The responsibility for the formation of tolerance in the younger generation falls on the shoulders of teachers, and teachers themselves must be the standards of a tolerant personality. They must respect the national, religious, and other group memberships to which their students belong, and they must skillfully organize conflict-free educational and educational activities in a heterogeneous children's collective. Only a tolerant teacher can contribute to the 
development of student tolerance.

The effect of educational activities on the formation of students' tolerance consists of passing through 3 levels of educational results: 1.) the acquisition of social knowledge by the student, 2.) the student gaining experience and a positive attitude towards the basic values of society, 3.) the student gaining experience of independent social action.

To paraphrase, at the first level, the teacher must give the child "moral knowledge" about what tolerance is, meaning that it is a value of modern society and that there are various cultures, nationalities, religions in the world, but all of them can and should peacefully coexist and interact. At the same time, the child may well not share and not accept this "moral knowledge" and not be able to implement it, but the main thing is that they are familiar with it.

At the second level, the teacher must create conditions for the development of the child's "moral skills" - the ability to work in a team, the ability to listen and hear another, to negotiate with them, to accept the differences of another person, and take them into account when communicating and interacting. Further, the must learn the ability to resolve with dignity and tact conflict situations. Again, the main thing is to show how to act correctly and enable the child to show all these skills in a play situation. But in a real-life situation, the child may not be interested in using them.

Therefore, the third level, the most desirable and difficult to achieve - "moral skill" - depends not only on the teacher, but also on the child themself, and on their environment. This is the child's inner acceptance of moral values as their own and the only possible behavior in situations of choice will be in accordance with them. It is towards this effect that out educational efforts must be directed.

\section{REFERENCE LIST}

Bezyuleva, G.V., Shelamova, G.M. (2003). Tolerantnost: vzglyad, poisk, reshenie (Psikhologiya dlya pedagoga), 164 p. ISBN 5-8391-0109-5 : 5000.

Grigoriev, G.V., Stepanov, P.V. (2010). Vneurochnaya deyatelnost shkolnikov. Metodicheskij konstruktor: posobie dlya uchitelya (Standarty vtorogo pokoleniya), 223 p. ISBN 978-5-09-020549-8.

Electronic fund of legal and regulatory documents: Federal Law N 273-FZ of December 21, 2012 "On Education in the Russian Federation" (as amended on September 1, 2021). URL: https://docs.cntd.ru/document/902389617 (date of access: 11-23-2021).

Khell, P., Zigler, D. (2008). Teorii lichnosti (Seriya «Mastera psikhologii»), 607 p. ISBN 978-5-88782-412-3.

Likhachev, D.S., Shmidt, S.O., Zholud, E.Yu., and Yakovlev, V.Yu. (2006). Pisma o dobrom, 315 p. ISBN 502-035671-9.

Mchedlov, M.P., Ojzerman, T.I., Mchedlova, E.M., Loginov, A.V., and Kafanova, E.N. (2004). Tolerantnost, 416 p. ISBN 5-250-01874-2.

Novikov, M.V., Nizhegorodczeva, N.V., Zlotnikova, T.S., Erokhina, T.I., Ledovskaya, T.V. (2011). Tolerantnost v sovremennom mire: opyt mezhdiscziplinarnykh issledovanij: sbornik nauchnykh statej, 357 p. ISBN 978-5-87555-725-5.

Official site of the United Nations: Declaration of Principles of Tolerance. (1995). URL: https://www.un.org/ru/documents/decl conv/declarations/toleranc.shtml, (date of access: 11-23-2021).

Semashko, M.A. (2007). Razvitie termina „tolerantnost“ $v$ gumanitarnykh naukakh. Elektronnyj nauchnopedagogicheskij zhurnal. URL: http://www.emissia.org/offline/2007/1204.htm, (date of access: 11-232021).

Shhekina, S.S. (2009). Osnovy pedagogiki mezhnaczionalnogo obshheniya v tezisakh, definicziyakh, pervoistochnikakh, $193 \mathrm{p}$.

Yamburg, E.A. (2014). Chto prinesyot uchitelyu novyj professionalnyj standart pedagoga? 175 p. ISBN 9785-09-034187-5. 